\title{
Effect of climatic conditions on height growth of red pine: Results of a provenance test in northwestern Ontario
}

\author{
by Michael Ter-Mikaelian and Colin Bowling²
}

\begin{abstract}
Response of height growth of red pine (Pinus resinosa Ait.) to changes in climatic conditions was analyzed using data collected in a 48-year-old provenance trial established in northwestern Ontario, Canada. Seed sources for the trial were collected from 23 provenances spanning the natural range of red pine. Mean monthly values of climatic variables were estimated from historical climatic data for 1971 to 2000. Quadratic transfer functions predicting mean tree height at age 48 and tree top height at age 50 were developed using the difference in climatic variables between the seed source provenances and the trial site. The transfer function for mean height at age 48 explained 59\% of data variation using the mean minimum temperature in July and sum of precipitation during June to February. For tree top height at age 50, the transfer function explained 55\% of data variation using mean minimum temperature in January and sum of precipitation during June to March. The developed equations can be used to select optimum seed sources for reforestation projects and to predict effects of climate change on stand growth in sites with climate conditions similar to those of the study site.
\end{abstract}

Keywords: transfer function, mean height, top height, temperature, precipitation, historical climate

\section{RÉSUMÉ}

On a analysé l'effet du changement des conditions climatiques sur la croissance en hauteur du pin rouge (Pinus resinosa Ait.) à laide des données recueillies dans un peuplement d'essai de provenance âgé de 48 ans situé dans le nord-ouest de l'Ontario au Canada. Les sources de semences de cet essai provenaient de 23 sites représentant la distribution naturelle du pin rouge. Les valeurs mensuelles moyennes des variables climatiques ont été estimées à partir des données climatiques historiques de 1971 à 2000. Les fonctions quadratiques de transfert permettant de prédire la hauteur moyenne à 48 ans et la hauteur maximale des arbres à 50 ans ont été élaborées en utilisant la différence entre les variables climatiques des sites de provenance des semences et celles du site de lessai. La fonction de transfert de la hauteur moyenne à 48 ans a permis dexpliquer $59 \%$ de la variation des données à partir de la température minimale moyenne de juillet et de la somme des précipitations de juin à février. Dans le cas de la hauteur maximale à 50 ans, la fonction de transfert a permis dexpliquer $55 \%$ de la variation des données en utilisant la température minimale moyenne de janvier et la somme des précipitations de juin à mars. Les équations ainsi obtenues peuvent servir à sélectionner les meilleures sources de semences dans le cas de projets de reboisement et à prédire les effets des changements climatiques sur la croissance des peuplements établis sur des sites où les conditions climatiques sont semblables à celles du site de l'essai.

Mots clés : fonction de transfert, hauteur moyenne, hauteur maximale, température, précipitation, climat historique

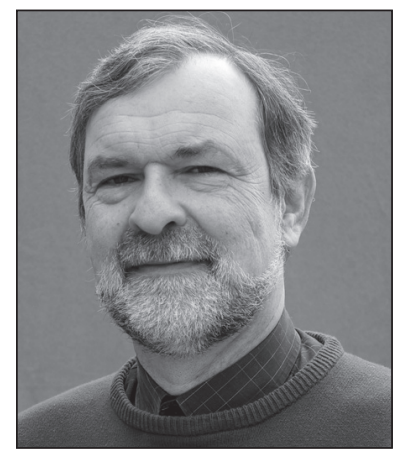

Michael Ter-Mikaelian

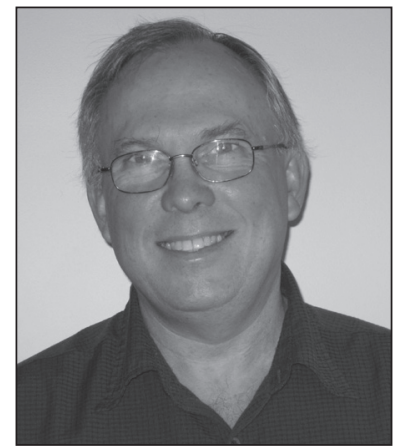

Colin Bowling

\section{Introduction}

Forests provide important ecological services such as wildlife habitat, carbon sequestration, and soil and water protection, and socio-economic services such as timber supply, and recreational, cultural, and spiritual benefits (IPCC 2007). Changes in climate resulting from global warming are expected to substantially affect these services through changes to the geographic distribution of forest tree species and to structure and functioning of forest ecosystems (IPCC 2007, McKenney et al. 2007). Therefore, predicting forest ecosystem responses to a changing climate is important for those developing forest management strategies aimed at preserving and enhancing forest resilience and productivity and those wanting to help forests adapt to climate change.

\footnotetext{
${ }^{1}$ Ontario Ministry of Natural Resources, Ontario Forest Research Institute, 1235 Queen St. East, Sault Ste. Marie, Ontario P6A 2E5. Corresponding author.E-mail: michael.termikaelian@ontario.ca

${ }^{2}$ Ontario Ministry of Natural Resources, Northwest Region, Regional Operations Division, Box 5080, 808 Robertson Street, Kenora, Ontario P9N 3X9.
} 
One of the important data sources for quantifying forest response to climate change is provenance trials (Schenk 1996). Initially, provenance trials were designed to identify optimum seed sources of a given tree species for reforestation, and included seeds from multiple geographic locations (provenances) planted in common experiments at one or several trial sites (Wang et al. 2010). More recently, data collected in provenance trials have been used to develop transfer functions, or equations, relating growth of trees originating from various seed sources to climatic differences between seed provenance and trial location (Rehfeldt et al. 1999, Andalo et al. 2005, Thomson and Parker 2008, Thomson et al. 2009). Such functions can be used in studies of climate change effects on species performance by substituting spatial climatic variation among provenances for long term temporal responses of tree species to changing climate (Wang et al. 2010).

In this paper we present transfer functions developed using data from a red pine (Pinus resinosa Ait.) provenance trial in northwestern Ontario, Canada. Red pine is a native North American conifer tree species distributed throughout northeastern North America, primarily near the Great Lakes and the St. Lawrence River (Rudolf 1990). Although the area occupied by red pine forests has greatly diminished since pre-European settlement, red pine remains a commercially and ecologically important tree species in the Great Lakes region (OMNR 1998) occupying about 800000 ha in Great Lakes states and 175000 ha in Ontario (Buckman et al. 2006, Watkins 2011). High volume growth rates, relative freedom from insect and disease damage, and low mortality make red pine a conifer of choice for reforestation projects (Buckman et al. 2006).

Despite its broad geographic distribution, red pine has historically been considered one of the most genetically uniform species in North America (Fowler and Morris 1977). However, more recent studies indicated that some genetic variation exists among both individuals and populations of red pine (Mosseler et al. 1992, DeVerno and Mosseler 1997, Echt et al 1998, Boys et al. 2005). Studies based on provenance trials also showed differences in survival rates, phenological traits, growth rates, photoperiodic response, and wood quality among trees grown from different seed sources (OMNR 1998). In their analysis of provenance trial data in northwestern Ontario, Rahi et al. (2010) reported statistically significant differences in height and diameter of 48-year-old pine trees. We further analyzed the data from this study, with the specific objective of developing transfer functions for average height at base age 48 and top height at base age 50 .

\section{Materials and Methods}

Data were collected from a red pine plantation located in McIlraith Township southwest of Sioux Lookout, Ontario (Maley and Bowling 1993, Rahi et al. 2010). The plantation is part of a larger-scale red pine provenance trial established as the 216 series by Natural Resources Canada and various co-operators between 1959 and 1964. Seed sources for the trial were collected from 23 provenances spanning the natural range of red pine. In 1958 , collected red pine seeds were sown at the nursery of the former Petawawa Forest Experiment Station in central Ontario and grown as $2+2$ transplant stock. The study plantation was established in 1962 in co-operation with Dryden Paper Company and is located at $49^{\circ} 28^{\prime} \mathrm{N}, 92^{\circ} 27^{\prime} \mathrm{W}$, close to the northern and western limit of the species' natural range.

The plantation site is a gravelly sandy ablation till that commonly supports fire-origin jack pine (Pinus banksiana Lamb.) stands under natural succession. Based on provincial yield tables (Plonski 1981), site quality is a Class 2 with an average jack pine height of approximately $15 \mathrm{~m}$ at 50 years. Prior to planting the site was bladed, resulting in the removal of most of the forest floor and uppermost mineral soil horizon. Bareroot seedlings were planted in a randomized complete block design with three replications. Each plot consisted of 25 trees $(5 \times 5)$ planted at $1.8-\mathrm{m}$ spacing. Single and double buffer rows of red pine surrounded each individual plot and each block, respectively. For more detail on the study design, the reader is referred to Rahi et al. (2010).

Height measurements were carried out in the fall of 2005. Height was measured for five to 10 trees per plot, randomly selected from the stems that were completely surrounded by living neighbours to avoid possible bias caused by openings due to mortality. For each plot, five trees were randomly selected from those measured, and their heights were averaged to produce mean provenance height per plot (MeanHt48; $\mathrm{m}$ ). The average of mean heights over three plots produced the mean height for each provenance included in the trial.

Climatic variables were estimated for each provenance and trial location using spatial climate models for Canada and the United States (McKenney et al. 2011, 2013). The models provide estimates of long-term average values of selected climatic variables based on 1971 to 2000 historical records using thin plate smoothing splines to interpolate and extrapolate climate station values as a function of latitude, longitude, and elevation. Estimates of climatic variables for provenances and trial location were produced by Daniel McKenney and Pia Papadopol (Canadian Forest Service, personal communication, 2014), and included mean, minimum, and maximum air temperature, and sum of precipitation, estimated for each month of the year; for a complete list of variables see McKenney et al. (2013).

Prior to developing transfer functions, we tested the data for similarity of provenance ranking among the three blocks. This was done to ensure that observed height differences among provenances were not an artifact of random variation in microsite conditions within blocks. Comparisons were conducted using $\tau$ test based on Kendall $\tau$ rank correlation coefficient (Encyclopedia of Mathematics 2011). Mean provenance heights per plot were ranked in descending order within each block, and rankings were tested among blocks using pair-wise comparisons. The tests indicated statistically significant dependence of rankings among blocks, with the highest $P$-value in three pair-wise comparisons of blocks equal to 0.0104. Using Bonferroni correction for multiple pair-wise tests, the overall $P$-value equalled 0.0312 , indicating similarity in provenance height ranking among the three blocks.

Transfer functions were constructed using quadratic regression models predicting mean tree height for each seed source from the difference in climatic values between seed provenance and trial location (Rehfeldt et al. 1999, Andalo et al. 2005). The first tested model had the following form: 
[1] MeanHt48 $=a_{0}+a_{i} \cdot\left[\right.$ TempMin prov $_{\text {(month, }}$, month $)$

- TempMin site $_{\text {inonth }}\left(\right.$ month $\left.\left._{i}\right)\right]+$

$a_{2} \cdot\left[\right.$ TempMin $_{\text {prov }}\left(\right.$ month $_{p}$ month $\left._{i}\right)$

- $\operatorname{TempMin}_{\text {site }}^{\text {provonth }}$ (month $\left.)\right]^{2}+$

$a_{3} \cdot\left[\right.$ TempMax ${ }_{\text {prov }}\left(\right.$ month $_{p}$ month $\left._{m}\right)$

- TempMax site $_{\text {pronth }}$ month $\left.\left._{m}\right)\right]+$

$a_{i}\left[\operatorname{TempMax}_{\text {prov }}^{\text {site }}\left(\right.\right.$ month $_{p}$ month $\left._{m}\right)$

- TempMax site $_{\text {prov }}\left(\right.$ month $_{p}$ month $\left.\left._{m}\right)\right]^{2}+$

$a_{5} \cdot\left[\operatorname{Prec}_{\text {prov }}\left(\right.\right.$ month , $_{p}$ month $)-\operatorname{Prec}_{\text {site }}\left(\right.$ month $_{\vec{p}}$ month $\left.)\right]$

$+a_{6} \cdot\left[\operatorname{Prec}_{\text {prov }}\left(\right.\right.$ month $_{\vec{P}}$ month $\left._{q}\right)-\operatorname{Prec}_{\text {site }}\left(\text { month }_{\vec{P}} \text { month }_{q}\right]^{2}$,

where indices prov and site refer to provenance number and study site, respectively;

TempMin and TempMax are historical minimum and maximum monthly temperature $\left({ }^{\circ} \mathrm{C}\right)$, respectively; Prec is historical mean monthly precipitation $(\mathrm{mm}) ; a_{0}, \ldots, a_{6}$ are regression coefficients; and indices in parentheses (month, month $_{i}$, month $_{p}$, month ${ }_{m}$, month $_{p}$, month ${ }_{q}$ ) identify the first and last months of a period (in consecutive months) over which the respective climatic variable is averaged (for temperature variables) or summed (for precipitation). First indices $(i, l, p)$ can have values between 1 and 12 (i.e., the period can start at any month between January and December), indices $j, m$, and $q$ can have values between $i+1$ and $i+11$, between $l+1$ and $l+11$, and between $p+1$ and $p+11$, respectively. For example, TempMin $_{\text {kprov }}(\mathrm{Jan}$, Mar) denotes historical minimum monthly temperature at the $k$-th provenance averaged over the period January to March. Of note is that values of indices allow calculation of climatic variables over periods "wrapping" around New Years; for example, $\operatorname{Prec}_{\text {kprov }}$ (Nov, Feb) denotes historical sum of mean monthly precipitation at the $k$-th provenance over the period November to January.

The second tested model had the form:

$$
\begin{aligned}
& \text { [2] MeanHt48 }=b_{0}+b_{i} \cdot\left[\text { TempMean }{ }_{\text {prov }} \text { (month, month }\right) \\
& \text { - TempMean } \left.\left.\text { site }_{\text {(month }}, \text { month }_{\mathrm{s}}\right)\right]+ \\
& b_{i} \cdot\left[\text { TempMean } \text { prov }_{\text {ste }} \text { (month, } \text { month }_{r}\right) \\
& \text { - TempMean }{ }_{\text {site }}\left(\text { month } \text {, month }_{s}\right]^{2}+ \\
& b_{3} \cdot\left[\operatorname{Prec}_{\text {prov }}\left(\text { month } \text { month }_{e}\right)-\operatorname{Prec}_{\text {site }}\left(\text { month }_{p} \text {, month }\right)\right]
\end{aligned}
$$

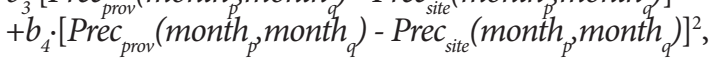

where TempMean is the historical mean monthly temperature $\left({ }^{\circ} \mathrm{C}\right), b_{0}, \ldots, b_{4}$ are regression coefficients; denotation of indices month ${ }_{r}$ and month follows the same convention as in eq. [1]. Mean temperature TempMean was not included in eq. [1] because it is well approximated by variables TempMin and TempMax. We also tested other climatic variables (e.g., sum of growing degree-days using a base temperature of $5^{\circ} \mathrm{C}$; temperature range between the mean temperature in the warmest month and the mean temperature in the coldest month) but those were rejected because they were not statistically significant predictors when used in combination with temperature and precipitation variables included in eq. [1]) and eq. [2].

Transfer functions were developed in two stages. In the first stage, eq. [1] and eq. [2]) were fitted to mean provenance heights averaged over three plots using all combinations of periods to calculate climatic variables, and all subsets of predictive variables; the latter subsets were created by forcing selected regression coefficients $a_{i}$ and $b_{i}$ to equal zero. For each tested equation, regression coefficients for predictive variables included in the equation were assessed for significance of difference from zero at $P$-value $=0.05$. The equation with the lowest standard error of estimate (SEE) and highest coefficient of determination $\left(R^{2}\right)$ was selected as the best predictive equation for tree height, meaning the equation form (predictive variables included in the equation) and periods (defined by indices month, month, month, month ${ }_{m}$, month, ${ }_{p}$, wonth, month $_{r}$, month) over which each predictive variable was calculated.

In the second stage, regression coefficients of the selected equation were estimated using a randomization technique (Crowley 1992, Pitt and Kreutzweiser 1998). The randomization technique was necessary to avoid pseudo-replication because the data included three estimates of mean tree height (one estimate per plot) for each seed source and only one estimate of each climatic variable at the seed provenance. One plot-mean height was randomly selected for each seed source (totalling 23 points) to form a randomized sample, and model parameters were estimated for this sample. Final model parameters were estimated as averages of the estimates obtained using 5000 randomized samples. The number of randomizations was based on when the mean and standard deviation for all model parameters converged. All programs for this analysis were written in Borland Pascal; procedures for generating random numbers and estimating parameters were taken from Press et al. (1994).

Applications such as yield curves used to predict stand net merchantable volume are generally based on variables such as top height or site index at a given basal age (e.g., Penner et al. 2008) rather than estimates of stand mean height. For the purpose of such applications, we developed transfer functions for top height at basal age $50(\mathrm{TopHt} 50, \mathrm{~m})$. Estimates of TopHt50 were obtained using an equation from Buckman et al. (2006) developed for stands older than 20 years:

$$
\text { [3] } \operatorname{TopHt}(A)=1.8604 \cdot \operatorname{TopH} H t 50 \cdot\left(1-\mathrm{e}^{-0.020098 \cdot \mathrm{A}}\right)^{1.439} \text {, }
$$

where $\operatorname{TopHt}(A)$ is the stand top height at age $A$ estimated as the average height $(\mathrm{m})$ of dominant and co-dominant trees. Top height for each plot was estimated as the average height of the tallest four trees to produce estimates of $\mathrm{TopHt}(48)$; since five trees were measured in most plots, selecting the four tallest trees was similar to the methodology used by Buckman et al. (2006) who included $75 \%$ of the tallest trees in their estimates of stand top height. For each plot, TopHt50 was estimated by resolving eq. [3], and the entire analysis described above was repeated to develop transfer functions for TopHt50.

\section{Results}

Provenances for each seed source are listed in Table 1 with respective mean heights at age 48 and top heights at age 50. Fitting eq. [1] and eq. [2] to the mean height at age 48 and site index at age 50 (values averaged over three blocks) required testing close to 64 million combinations of predictive variables and periods over which these variables were calculated. Tested combinations resulted in over 60000 equations for each dependent variable, in which all regression coefficients were significantly different from zero at $P$-value $=0.05$. The best equation for mean height included the linear and squared terms for mean monthly minimum temperature $\left({ }^{\circ} \mathrm{C}\right)$ for July and the linear term for mean monthly precipitation $(\mathrm{mm})$ summed over the period June to February, with $R^{2}$ and SEE equal to 0.803 and 0.246 , respectively. Estimating regression coefficients of the best equation using the re-sampling technique produced the following equation: 
[4] MeanHt48 $=15.512-0.367 \cdot[$ TempMin $\left.\operatorname{TempMin}_{\text {site }}(J u l)\right]+0.301 \cdot\left[\mathrm{TempMin}_{\text {prov }}^{\text {prov }}(\mathrm{Jul})-\right.$ $\left.\operatorname{TempMin}_{\text {site }}(J u l)\right]^{2}-0.00398 \cdot\left[\operatorname{Prec}_{\text {prov }}\right.$ prov, $\left.\mathrm{Feb}\right)-$ $\operatorname{Prec}_{\text {site }}($ Jun,$\left.F e b)\right], \mathrm{R}^{2}=0.594, \mathrm{SEE}=0.418$

The best equation for top height at age 50 fitted to the averages of three blocks included the linear and squared terms for mean monthly minimum temperature $\left({ }^{\circ} \mathrm{C}\right)$ for January and the linear term for mean monthly precipitation $(\mathrm{mm})$ summed over the period June to March, with $\mathrm{R}^{2}$ and SEE equal to 0.764 and 0.279 , respectively. Estimating regression coefficients of the best equation using the re-sampling technique produced the following equation:

\section{[5] TopHt50 $=16.194+0.190 \cdot[$ TempMin $(J a n)-$

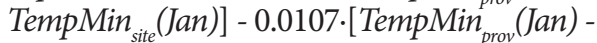 $\left.\operatorname{TempMin}_{\text {site }}(\mathrm{Jan})\right]^{2}-0.00461 \cdot\left[\operatorname{Prec}_{\text {prov }}(\right.$ pun, Mar $)$ - $\left.\operatorname{Prec}_{\text {site }}(J u n, M a r)\right], R^{2}=0.552, \mathrm{SEE}=0.456$}

The quality of fit for eq. [4] and eq. [5] is illustrated in Fig. 1 , which shows observed versus predicted values of (a) mean height at age 48 and (b) top height at age 50. Each dot represents one plot-mean value, with the diagonal line indicating equivalent observed and predicted values. Fig. 2 depicts transfer functions developed for two levels of the second predictive variable (difference in precipitation between the location of the seed provenance and the trial). The two selected levels correspond to $25^{\text {th }}$ percentile (solid line) and $75^{\text {th }}$ percentile (dashed line) of the observed range of the difference in precipitation between the seed provenance and trial location summed over the period
June to February (Fig. 2a; transfer function for the mean height at age 48) and June to March (Fig. 2b; transfer function for the top height at age 50). The circles show observed values (mean of three plots) of height at age 48 (Fig. 2a) and top height at age 50 (Fig. 2b); hollow and solid circles correspond to the observed height values for 0 to $50^{\text {th }}$ and $50^{\text {th }}$ to $100^{\text {th }}$ percentile ranges, respectively, of the difference in precipitation between the location of the seed provenance and the trial.

\section{Discussion}

Developed transfer functions explained $59 \%$ and $55 \%$ of the variation in red pine mean height at age 48 and top height at age 50, respectively. For comparison, Thomson and Parker (2008) reported that quadratic transfer functions fitted to the data from individual planting sites in a multi-site provenance trial with jack pine explained up to $62 \%$ of variation in mean tree height at age 39; Cauchy transfer functions fitted to the data from individual planting sites in the same trial explained between $17 \%$ and $41 \%$ of the variation in mean tree height (depending on the individual site and predictive variable used in the function). Similar results were produced by Thomson et al. (2009) in a 36-year-old black spruce provenance trial in which transfer functions for individual planting sites explained between $12 \%$ and $34 \%$ of variation in mean tree height. Quadratic transfer functions explained between $27 \%$ and $39 \%$ of variation in height of 1-year-old white birch seedlings (Oke and Wang 2013).

The amount of explained variation was noticeably higher when equations were fitted to mean height at age 48 and top height at age 50 averaged over three blocks. This was the result

Table 1. Locations and geographic coordinates (latitude, longitude) of seed sources included in red pine provenance trial established in Mcllraith Township, Ontario, as well as mean tree height (m) measured at age 48 and top height (m) estimated at age 50

\begin{tabular}{|c|c|c|c|c|c|}
\hline Location & Province or state & Latitude $\left({ }^{\circ} \mathbf{N}\right)$ & $\begin{array}{l}\text { Longitude } \\
\left({ }^{\circ} \mathrm{W}\right)\end{array}$ & $\begin{array}{c}\text { Mean height }(\mathrm{m}) \text { at } \\
\text { age } 48\end{array}$ & $\begin{array}{c}\text { Top height }(\mathrm{m}) \text { at } \\
\text { age } 50\end{array}$ \\
\hline Stanley & Nova Scotia & 45.1 & 63.9 & 13.96 & 14.63 \\
\hline Rawdon & Quebec & 46.0 & 73.7 & 14.44 & 15.62 \\
\hline Grand Lake & New Brunswick & 46.0 & 66.1 & 14.49 & 15.66 \\
\hline Lake State & Wisconsin & 45.6 & 91.0 & 14.87 & 16.26 \\
\hline Grand Traverse Co. & Michigan & 44.7 & 85.5 & 14.89 & 16.16 \\
\hline Sturgeon Falls & Ontario & 46.4 & 79.9 & 14.92 & 15.82 \\
\hline Douglas & Ontario & 45.5 & 76.9 & 15.04 & 16.42 \\
\hline Schoolcraft Co. & Michigan & 46.2 & 86.2 & 15.15 & 16.59 \\
\hline Boulder Jct. & Wisconsin & 46.0 & 89.7 & 15.20 & 16.02 \\
\hline Oneida Co. & Wisconsin & 45.9 & 89.7 & 15.25 & 16.55 \\
\hline Cass Lake & Minnesota & 47.4 & 94.7 & 15.31 & 16.39 \\
\hline Clubhouse Lake & Minnesota & 47.5 & 93.5 & 15.32 & 16.30 \\
\hline Dryden & Ontario & 49.8 & 92.9 & 15.41 & 16.28 \\
\hline Thistledew Lake & Minnesota & 47.8 & 93.3 & 15.41 & 16.25 \\
\hline Chippewa Nat. For. & Minnesota & 47.3 & 94.0 & 15.43 & 16.16 \\
\hline Grand Bend & Ontario & 43.3 & 81.8 & 15.43 & 16.15 \\
\hline Presque Isle Co. & Michigan & 45.4 & 84.2 & 15.52 & 16.82 \\
\hline Itasca Park & Minnesota & 47.3 & 95.3 & 15.57 & 16.37 \\
\hline Lake Thirteen & Minnesota & 47.3 & 94.5 & 15.74 & 16.75 \\
\hline Fort Frances & Ontario & 48.6 & 93.4 & 15.75 & 16.51 \\
\hline Superior Nat. For. & Minnesota & 47.5 & 90.8 & 15.89 & 16.83 \\
\hline Six Mile Lake & Minnesota & 47.3 & 94.1 & 15.90 & 17.09 \\
\hline Trout Lake & Wisconsin & 46.0 & 89.7 & 16.20 & 17.02 \\
\hline
\end{tabular}



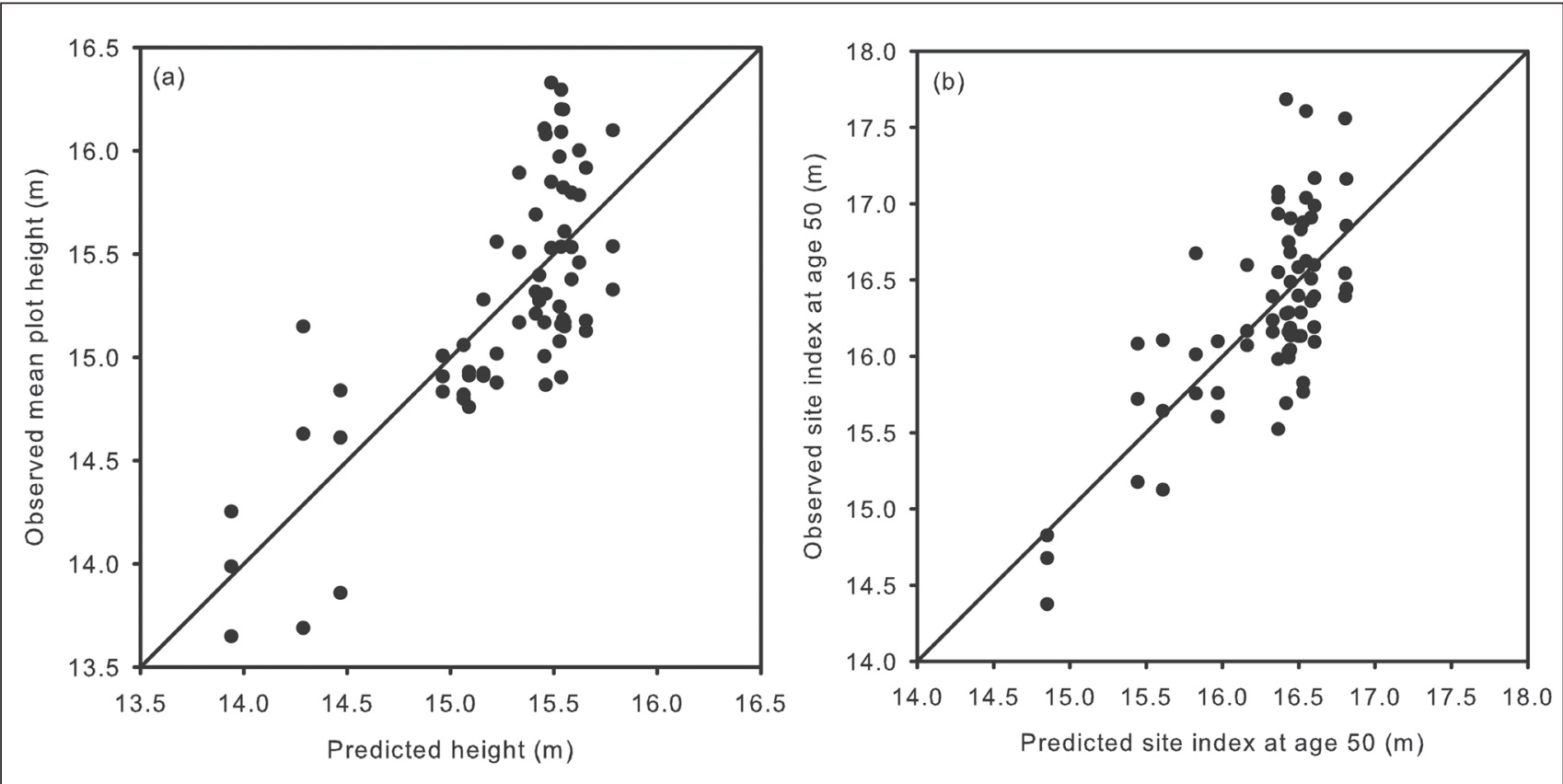

Fig. 1. Predicted versus observed (a) mean height at age 48 and (b) top height at age 50 of plantation-grown red pine in northwestern Ontario. Each dot represents a plot-mean value.

of substantial variation in plot-mean values among blocks. In general, a lower amount of explained variation may be indicative of missed predictive variables and/or incorrectly chosen equation form. However, in this particular case, the differences in dependent variables among blocks could not be attributed to the difference in climate between provenances and planting site since the difference in selected climatic variables was the same for all three plot means for a given seed source.

A common approach to selecting predictive climatic variables when developing seed transfer functions is to limit the tests to an a priori set that usually includes monthly or seasonal means of selected variables (e.g., Thomson and Parker 2008, Thomson et al. 2009, Oke and Wang 2013). This is likely due to logistical difficulties associated with testing multiple combinations of variables and periods of the year over which these variables are estimated. We overcame this limitation by developing a computer program that automated testing of equations with various combinations of predictive variables. This approach substantially increased the total number of tested equations, most of which would likely have been missed if we attempted to

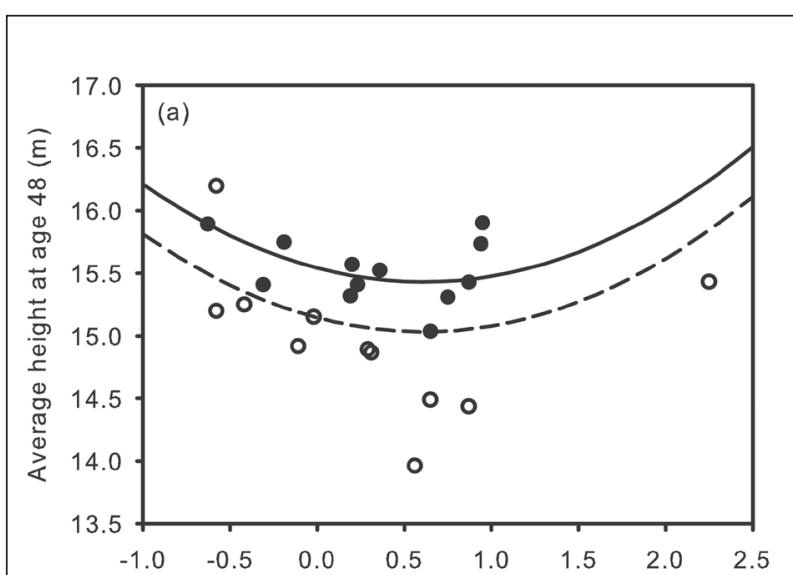

Minimum temperature in July $\left({ }^{\circ} \mathrm{C}\right)$ (provenance origin - trial site)

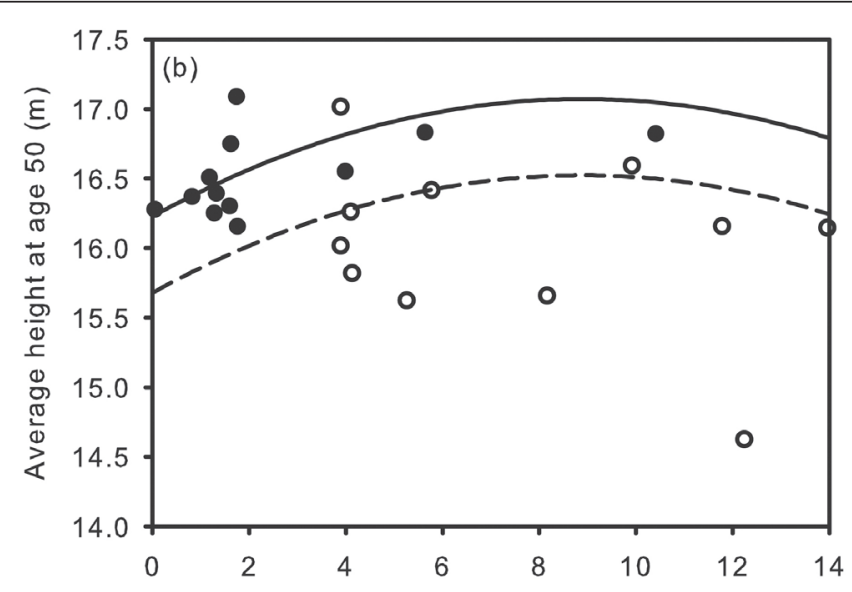

Minimum temperature in January $\left({ }^{\circ} \mathrm{C}\right.$ ) (provenance origin trial site)

Fig. 2. Transfer functions for (a) mean height at age 48 and (b) top height at age 50 of plantation-grown red pine corresponding to $25^{\text {th }}$ (solid line) and $75^{\text {th }}$ percentile (dashed line) of the observed range of differences in precipitation between the seed provenance and study location. Circles show observed values of (a) the mean height at age 48 and (b) top height at age 50 corresponding to 0 to $50^{\text {th }}$ percentile (solid circles) and $50^{\text {th }}$ to $100^{\text {th }}$ percentile (hollow circles) of the observed range of differences in precipitation. 
test them manually one at a time. In this study, tested variables included mean, maximum, and minimum temperature and total precipitation estimated for various numbers of consecutive months within a two-year span. Other climatic variables (such as mean monthly temperature and growing degree-days) were not significant predictors when tested in combination with the included temperature and precipitation variables. The same approach, however, could be expanded to include other climatic variables of choice (e.g., ratio of temperature to precipitation, Rehfeldt et al. 1999; maximum daily temperature, Andalo et al. 2005).

The disadvantage of the above approach is that it results in a high number of tested equations in which all regression coefficients statistically differ significantly from zero, with many equations producing comparable results in terms of the amount of explained variation and SEE. For example, when equations predicting mean height at age 48 were fitted to site-mean values (average of three blocks), two equations produced SEE $<0.25$; 102 equations produced SEE between 0.25 and 0.26 ; 352 equations produced SEE between 0.26 and 0.27 ; and so on. Such similarity stems from the fact that, for a given combination of predictive variables, a slight modification of the period over which the variables were calculated changed the fit results only marginally. For example, if eq. [4] were modified by calculating mean monthly minimum temperature for the period July to August (as opposed to a single month value for July) and re-fitted to plot means using the re-sampling technique, the amount of explained variation and SEE would equal 0.566 and 0.433 , respectively.

Ideally, climatic variables selected for transfer functions should be biologically meaningful, i.e., reflect an established causal relationship between climate and tree height growth. However, the difficulty with choosing only biologically meaningful predictive variables is two-fold. First, causal relationships are not known to the level of confidence that would justify $a$ priori selection among several similar variables; for a detailed discussion of such relationships the reader is referred to the review paper by Schenk (1996). For example, one cannot say with any degree of certainty that mean monthly minimum temperature for July to August is biologically more meaningful than that for July alone, and vice versa. Second, even if causal relationships between climate and tree height growth were reasonably well understood, selecting transfer functions based on biologically meaningful variables would require bypassing hundreds of equations that may include less meaningful variables but produce better statistical results. As stated by Schenk (1996), using "purely empirical approaches that are soundly based on measurements would be better than relying on intuitive assumptions about the relationship between physiological processes and growth." In keeping with the latter philosophy and with practical applications of developed transfer functions in mind, we chose equations that produced the best fit to the field measurements over those that might be more biologically interpretable.

Similar logic was used in selecting the transfer function for mean height at age 48 that had a convex shape with regard to mean monthly minimum temperature (Fig. 2a), i.e., positive regression coefficient for the third term in eq. (4). Commonly, transfer functions are expected to be concave, with height reaching maximum at some intermediate value of selected climatic variable and diminishing towards the ends of the tested range of values, although the scientific literature does contain other examples of convex transfer functions (e.g., Oke and Wang 2013). Here again the choice of the transfer function was dictated by the empirical data; selecting a concave function would effectively mean ignoring the results of statistical analysis in favour of an a priori defined transfer function shape.

Our analysis confirmed the results reported by Rahi et al. (2010) who found statistically significant differences in mean height attained by age 48 among seed sources. These results contrast with the historically accepted notion of uniformity of red pine (e.g., Fowler and Morris 1977) but concur with results of more recent studies that indicated genetic variation among individuals and populations of red pine (Mosseler et al. 1992, DeVerno and Mosseler 1997, Echt et al. 1998, Boys et al. 2005); for a review of studies on height variation among red pine seed sources the reader is referred to Rahi et al. (2010). Since height variation observed in a given study has been suggested to result from microsite variation among plots with different provenances (e.g., OMNR 1998), we tested seed sources for similarity of height rankings among the three blocks in this study. Despite numerical differences in height at age 48 in individual blocks indicating differences among blocks (Fig. 1), seed source ranking by height within a block was similar among the three blocks. Since plots within a given block were randomly assigned to seed sources, it is highly unlikely that seed sources were aligned along the same gradient in some microsite factor within each block making microsite variation an unlikely cause of observed variation in tree height among seed sources.

Height growth of red pine is known to be relatively unaffected over a wide range of stem spacings; however, it has been reported as slower in dense stands (Sims et al. 1990). The effect of narrow spacings on mean height has also been reported for other trees species (e.g., Lanner 1985, Peracca and O'Hara 2008). The original planting spacing in this study (at $1.8 \mathrm{~m}$ ) resulted in a very dense stand, especially since the survival rate was very high $(\geq 96 \%)$ in all plots (Rahi et al. 2010). This may have affected the reliability of the transfer function based on mean height. On the other hand, top height growth of red pine has been found to be unaffected by tree spacing even in very dense stands (Sims et al. 1990); similar results have been reported for ponderosa pine (Pinus ponderosa Dougl. ex P. \& C. Laws.) by Ritchie et al. (2012). Since calculation of top height at age 50 was based on estimated top height, the transfer function developed for top height may provide more reliable results than that developed for height at age 48 .

The transfer functions that we developed can be used in management decisions about reforestation to help select seed sources best adapted to current and future climate at a given planting location (Rehfeldt 1995, O'Neill et al. 2008), to develop assisted migration systems (Rehfeldt et al. 2001), and in models predicting effects of climate change on stand growth (Wang et al. 2010). As the analysis was based on data collected from a single planting site, applicability of the developed functions is restricted to sites with climatic conditions similar to those of the trial site; as pointed out by Wang et al. (2010), individual transfer functions (i.e., developed for one planting site) are test site-specific and their application to substantially different sites may be problematic. Further studies are required to test the generality of developed functions and their applicability to a broader range of sites and climatic conditions. 


\section{Acknowledgements}

We thank Dale Simpson (Canadian Forest Service) for valuable contribution to this study; Pia Papadopol and Daniel McKenney (Canadian Forest Service) for providing climatic data for the study sites; and Stephen Colombo, Lisa Buse (both with Ontario Ministry of Natural Resources), and two anonymous reviewers for their helpful comments on an earlier version of this manuscript.

\section{References}

Andalo, C., J. Beaulieu and J. Bousquet. 2005. The impact of climate change on growth of local white spruce populations in Quebec, Canada. Forest Ecology and Management 205: 169-182.

Boys, J., M. Cherry and S. Dayanandan. 2005. Microsatellite analysis reveals genetically distinct populations of red pine (Pinus resinosa, Pinaceae). American Journal of Botany 92(5): 833-841.

Buckman, R.E., B. Bishaw, T.J. Hanson and F.A. Benford. 2006. Growth and yield of red pine in the Lake States. USDA Forest Service, General Technical Report NC-271, St. Paul, MN. 114 p.

Crowley, P.H. 1992. Resampling methods for computation-intensive data analysis in ecology and evolution. Annual Review of Ecology, Evolution, and Systematics 23: 405-447.

DeVerno, L.L. and A. Mosseler. 1997. Genetic variation in red pine (Pinus resinosa) revealed by RAPD and RAPD-RFLP analysis. Canadian Journal of Forest Research 27: 1316-1320.

Echt, C.S., L.L. DeVerno, M. Anzidei and G.G. Vendramin. 1998. Chloroplast microsatellites reveal population genetic diversity in red pine, Pinus resinosa Ait. Molecular Biology 7: 307-316.

Encyclopedia of Mathematics. 2011. A.V. Prokhorov (originator). Kendall coefficient of rank correlation [online]. Available at http:// www.encyclopediaofmath.org/index.php?title=Kendall_coefficient_ of_rank_correlation\&oldid=13189 [Accessed 4 February 2014].

Fowler, D.P. and R.W. Morris. 1977. Genetic diversity in red pine: evidence for low genetic heterozygosity. Canadian Journal of Forest Research 7: 343-347.

[IPCC] Intergovernmental Panel on Climate Change. 2007. Climate Change 2007: Impacts, Adaptation and Vulnerability. Contribution of Working Group II to the Fourth Assessment Report of the Intergovernmental Panel on Climate Change, M.L. Parry, O.F. Canziani, J.P. Palutikof, P.J. van der Linden and C.E. Hanson, eds. Cambridge University Press, Cambridge, UK. 976 p.

Lanner, R.M. 1985. On the insensitivity of height growth to spacing. Forest Ecology and Management 13: 143-148.

Maley, M. and C. Bowling, 1993. A 30-year re-measurement of a red pine provenance trial: implications for management in northwestern Ontario. Ontario Ministry of Natural Resources. Technical Note No. 22. $10 \mathrm{p}$.

McKenney, D., M. Hutchinson, P. Papadopol, K. Lawrence, J. Pedlar, K. Campbell, E. Milewska, R.F. Hopkinson, D. Price and T. Owen. 2011. Customized spatial climate models for North America. Bulletin of the American Meteorological Society, December 2011: 1611-1622.

McKenney, D., J. Pedlar, M. Hutchinson, P. Papadopol, K. Lawrence, K. Campbell, E. Milewska, R.F. Hopkinson and D. Price. 2013. Spatial climate models for Canada's forestry community. The Forestry Chronicle 89: 659-663.

McKenney, D.W., J.H. Pedlar, K. Lawrence, K. Campbell and M.F. Hutchinson. 2007. Potential impacts of climate change on the distribution of North American trees. Bioscience 57: 939-948.

Mosseler, A., K.N. Egger and G.A. Hughes. 1992. Low levels of genetic diversity in red pine confirmed by random amplified polymorphic DNA markers. Canadian Journal of Forest Research 22: 1332-1337.

Oke, O.A. and J.R. Wang. 2013. Assessing effects of seed source and transfer potential of white birch populations using transfer functions. Open Journal of Ecology 3: 359-369.
[OMNR] Ontario Ministry of Natural Resources. 1998. A silvicultural guide for the Great Lakes-St. Lawrence conifer forest in Ontario. 1998. Ontario Ministry of Natural Resources, Queen's Printer for Ontario. Toronto, ON. 424 p. Available at http://www.mnr.gov.on.ca/en/ Business/Forests/Publication/MNR_E000325P.html [Accessed 1 February 2014].

O’Neill, G.A., A. Hamann and T. Wang. 2008. Accounting for population variation improves estimates of the impact of climate change on species' growth and distribution. Journal of Applied Ecology 45: 1040-1049.

Penner, M., M. Woods, J. Parton and A. Stinson. 2008. Validation of empirical yield curves for natural-origin stands in boreal Ontario. The Forestry Chronicle 84: 704-717.

Peracca, G.G. and K.L. O’Hara. 2008. Effects of growing space on growth for 20-year-old giant sequoia, ponderosa pine, and Douglas-fir in the Sierra Nevada. Western Journal of Applied Forestry 23: 156-165. Pitt, D.G. and D.P. Kreutzweiser. 1998. Application of computerintensive statistical methods to environmental research. Ecotoxicology and Environmental Safety 39: 78-97.

Plonski, W.L. 1981. Normal yield tables (metric) for major forest species of Ontario. Ontario Ministry of Natural Resources, Forest Research Group, Toronto, ON. 40 p.

Press, W.H., B.P. Flannery, S.A. Teukolsky and W.T. Vetterling. 1994. Numerical Recipes in Pascal. Cambridge University Press, Port Chester, NY. 759 p.

Rahi, A.A, C. Bowling and D. Simpson. 2010. A red pine provenance test in northwestern Ontario: 48-year results. The Forestry Chronicle 86: $348-353$.

Rehfeldt, G.E. 1995. Genetic variation, climate models and the ecological genetics of Larix occidentalis. Forest Ecology and Management 78:21-37.

Rehfeldt, G.E., N.M. Tchebakova and L.K. Barnhardt. 1999. Efficacy of climate transfer functions: introduction of Eurasian populations of Larix into Alberta. Canadian Journal of Forest Research 29: 1660-1668. Rehfeldt, G.E., W.R. Wykoff and C.C. Ying. 2001. Physiologic plasticity, evolution, and impacts of a changing climate on Pinus contorta. Climatic Change 50: 355-376.

Ritchie, M., J. Zhang and T. Hamilton. 2012. Effects of stand density on top height estimation for ponderosa pine. Western Journal of Applied Forestry 27: 18-24.

Rudolf, R.O. 1990. Pinus resinosa Ait., red pine. In R.M. Burns and B.H. Honkala (eds.). Silvics of North America, vol. 1, Conifers. pp. 442-455. USDA Forest Service, Agriculture Handbook 654. Washington, DC.

Schenk, H.J. 1996. Modeling the effects of temperature on growth and persistence of tree species: A critical review of tree population models. Ecological Modelling 92: 1-32.

Sims, R.A., H.M. Kershaw and G.M. Wickware. 1990. The autecology of major tree species in the North Central Region of Ontario. Ontario Ministry of Natural Resources, Northwestern Ontario Forest Technology Development Unit Technical Report 48, Thunder Bay, ON. 126 p. Available at https://cfs.nrcan.gc.ca/publications?id=22213 [Accessed 4 February 2014].

Thomson, A.M. and W.H. Parker. 2008. Boreal forest provenance tests used to predict optimal growth and response to climate change. 1. Jack pine. Canadian Journal of Forest Research 38: 157-170.

Thomson, A.M., C.L. Riddell and W.H. Parker. 2009. Boreal forest provenance tests used to predict optimal growth and response to climate change: 2. Black spruce. Canadian Journal of Forest Research 39: 143-153.

Wang, T., G.A. O'Neill and S.N. Aitkens. 2010. Integrating environmental and genetic effects to predict responses of tree populations to climate. Ecological Applications 20:153-163.

Watkins, L. 2011. The Forest Resources of Ontario 2011. Ontario Ministry of Natural Resources, Forest Evaluation and Standards Section, Forests Branch, Sault Ste. Marie, ON. 307 p. 